リピオドール化制癌剤を用いた肝癌の選択的癌化学療法

\begin{tabular}{|c|c|c|c|c|c|}
\hline 兼松 & 隆之 & 井口 & 潔 & 古田斗志也 & 竹中 \\
\hline 園田 & 孝志 & 江崎 & 卓弘 & 矢永 勝彦 & 杉町 \\
\hline 田村 & 正三 & 松浦 & 啓一** & & \\
\hline
\end{tabular}

要 旨：水溶性制癌剤をリピオドールに懸濁化するため“リピオドール・ウログラフィン”シ ステムを考案し，これを肝癌55症例の治療に応用した。 その結果, 次の結論を得た。

（1）制癌剂含有油性造影剂を腫瘍栄養血管内に投与すると, 腫瘍部に選択的に停滞するが, その程度は腫煬血管が豊富なもの程顕著であった。

（2）制癌剂の組織内濃度は83\%の症例で腫湯部が非腫煬部に比べ高値であった。

（3）抗腫瘍効果に関しては，血中 $\alpha$-フェトプロテイン值低下を $78 \%$ に, CT 像上での腫瘍縮 小を $14 \%$ 症例に認めた.

（4）組織学的には主腫瘍の完全壊死が得られた症例です, 周辺組織へ浸潤した癌巣の一部は 死隇していない所見もみられた。

（5）以上，本療法の有効性を確認したが，根治性には疑問があり，切除不能肝癌の治療手段， あるいは肝切除術の補助療法として位置付けられるべきものであろう。

索引用語：リピオドール 60\%ウログラフィン 肝癌 選択的癌化学療法

\section{緒言}

癌化学療法は正常細胞には障害を与えず, 癌細胞の みを死隇させることが理想である。幾多の制癌剤が開 発され，臨床的にはそれなりの効果る得られているる のの, 理想的な選択的癌化学療法の実現までには，末 だ至っていない，薬剤自体にその選択性を委ねること ができない現在, 薬剤の作用を癌部のみに働かせるた めの工夫が必要となる。

油性造影剤リピオドールを腫湯の栄養動脈内に投与 すると, 選択的かつ長期にわたり癌組織内のみに停滞 する.この特徵を生かせば，選択的癌化学療法も可能 となるのではないかと期待される。我々は，この油性 造影剤リピオドールの腫瘍特異性に注目し，肝癌を中 心に, 一連の選択的癌化学療法の研究を行ってきた。

\section{歴史的背景}

リピオト゚ール (Lipiodol Ultra-Fluid) は, ヨード化 ケシ油脂肪酸エチルエステルで，そのヨード含量は30 w/w\%である。この油性造影剤は子宮・卵管造影やリ ンバ管造影に広く用いられてきだ．1966年, Idezuki

“九州大学第 2 外科

**九州大学放射線科
等は, 肝リンバ系の研究過程で実験的に犬の門脈内に リビオドールを注入したところ，門脈枝が長期にわた り造影されることを認め, 副作用もないところから， リピオドール門脈造影は肝の space-occupying lesion (SOL)の診断に有用であることを報告しだ)。これに 対し1979年, 中熊らは, 切除不能肝癌症例に対して肝 動脈結禁を行い, 肝動脈内にチューブ挿入し, 結禁肝 動脈内にリピオドールを注入したところ，リビオドー ルが選択的に腫湟に停滞する現象を認めだ).1982年, 今野らは，油性高分子制癌剂 stylene maleic acid neocarzinostation (SMANCS)をりビオドール溶解 させ，原発性肝癌に対し，化学療法を行い，その有用 性を報告しだ!。これらを契機としてりピオドールを 用いた化学療法が次第に注目されだした。しかし、リ ピオドールは油性造影郕であるが，親油性制癌剤は覀 めて少なく，また一般の主な制癌剤は水溶性であり， リビオドールに溶解できないことなどすあって一般化 しにくかったように思われる。そこで，我々は，この リピオドールの特徵を生かし，かつ，一般の水溶性制 癌剂（アドリアマイシン, マイトマイシン, 5-FU 等) をリピオドールに溶解するための工夫を行った。 その 結果, $60 \%$ ウログラフィンを媒介させる方法を考案す 
るに至っだ5.

\section{材料および方法}

1）リビオドール・水性制癌凨照濁法

水溶性制癌剤と油性造影剤を混合するための媒介物 質として, 水性ヨード化造影剤60\%ウログラフィンに 着目した，この造影剂に着目した由縁は，その比重の ためである。60\%ウロクラフィンの比重は 1.328 - $1.332\left(20^{\circ} \mathrm{C}\right)$ であり，これはリビオドールの 比重1.275 1.290々ほぼ同じである。比重が等しいた め, 両者は water-in-oil の型で懸濁化が可能である. 勿 論, この水性造影剂は水溶性制癌剂を容易に溶解し得 る.ウログラフィンとリピオドールの混合比は，ほぼ 1：3 位が最適である，制癌郕としては，従来から， 原発性肝癌に最も良く使用されているアドリフマイシ ン（ADM）を用いた。

実際には，以下の手順で，薬剤の調整を行っている。

(1) ADM 10〜40mgを60\%ウログラフィン $1 \sim 2 \mathrm{~m} l$ に溶解する。

(2)この溶液にリビオドール3 $6 \mathrm{~m} l$ を加える.

(3) 用手的振盪あるいは超音波操作にて懸濁液を作 製する.

\section{2) Lipiodolization}

家鬼を用いた実駼癌で，ADM 含有リビオドールは 著効を示すのに対し，リピオドール単独では効き目が ないことがわかっだ).すなわち、リビオドールは制癌 剤を癌部まで選択的に運搬する役目をはたしているに すぎす，その主な抗腫瘍効果は，制癌剤によって得ら れるものと考光られる。従って，我々は，この方法の 有効性のメカニズムは, 従来の経動脈的塞栓術(TAE) のそれとは異なるものであるという観点から本法を Lipiodolization と名付けだ!. 更に, ウログラフィンを 媒介し、リビオドール中に制癌戍を㲘濁させることを 制癌㨈のリビオドール化と呼ぶことにした。

経カテーテル的に肝動脈内にリピオドールを注入す ると、リビオドールは次第に小さな油滴となり，動脈 血の流れに乗って運ばれていく，非癌部では，さらに 細かな油滴となって，消失していくが，癌部では，リ ピオドールの粒子が次々に貯留していく.この現象は， hypervascular mass 程著明に認められる (Fig. 1).

\section{3) 対 象}

昭和57年10月から昭和59年 3 月までに， Lipiodolization を行った原発性肝癌52例, 転移性肝癌 3 例, 合計55例（令 46例, 우 9 例, 平均58葴) を対象 とした.フドリフマイシン投与量は, 年龄, 全身状熊,

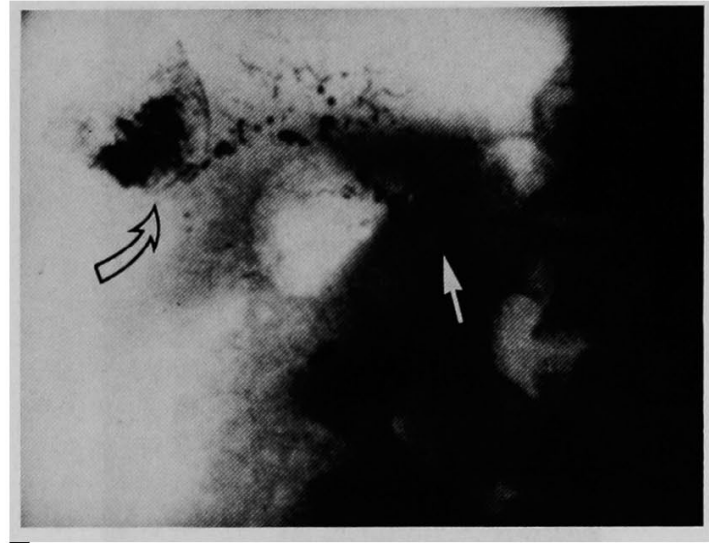

Fig. 1 Administration of Lipiodolized antitumor agent. Oily contrast medium given via a catheter (small arrow) is dispersed into various sized droplets in the blood stream. Droplets of oil are trapped and remain selectively in the tumor of the liver (large arrow).

肝機能などを考虑して決定し，リピオドール量は，睡 瘍の大きさ，カテーテルの挿入部などを参考とした。

\section{成 績}

1）診断的意義

(1) 腹部単純 $レ$ 線

リピオドールの貯留は，腹部単純レ線にても投与後 数週一数カ月にわたり認められる.リピオドールは主 腫瘍のみならず，周辺の娘結節にも，停滞している (Fig. 2)，単純レ線上,リピオドールの停滞程度を次 の如く 4 段階に分けた。

(H)：腫瑒全体に濃く停滞

$(+)$ : 腫瘍全体に淡く停滞，一部に濃い停滞を認め る.

(土): ごく一部のみに停滞

$(-)$ : 停滞なし

以上の規定によると, 原発性肝癌52例のレ線像では, (+) 24 例 (46\%)，(+)20例 (38\%)，（士) 5 例 (10\%), (一) 3 例 $(6 \%)$ であった。転移性肝癌 3 例でのそれ は, (+) は 1 例むなく $(+),( \pm),(-)$ が各々 1 例 のみであった。

(2) CT 像

肝内リピオドール停滞状況をみる上で，最も有効な 手段はCT 像である，腫場に一致して，リピオドール の光った像が認められる. 本法施行後の CTは, 病変 の広がりを鮮明にする点です有用である。

（3）超音波像 


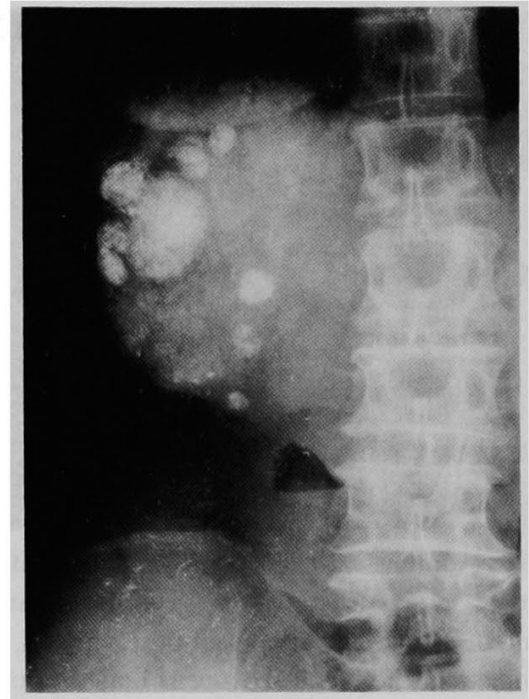

Fig. 2 Plain x-ray taken 3 days after Lipiodolization shows a characteristic accumulation of oily contrast medium in the main tumors. The deposits of oily substance are also evident in the multiple metastatic nodules in the liver.

元来, 肝腫湯は hypoechoic として描写されること が多いが，リピオドール投与により輝きを増すように なる.すなわち hyperechoic となり, 腫湟周辺の halo も明瞭となる (Fig. 3).

(4) 血管造影像

Lipiodolization 施行直後に, 通常の血管造影を行 5 之, 治療前に比べ, vascularity の低下を認めるが, 消 失までは至らない。このことは，リビオドールの停带 により,腫瘍への流入血液量の減少はもたらすものの， スポンゼルや，ぜロフォームを用いた embolizationの よらに，腫湯栄養血管を塞栓してしまうものではない ことを物語っている。

2）切除標本による検討

（1）肉眼標本の軟線撮影

Lipiodolization 後の切除標本あるいは剖検標本を 軟線撮影すると，畽瘍に一致して、リピオドールの停 漟がさらに明瞭となる (Fig. 4).

(2) 組織学的検討

リピオドールの存在部位を組織学的に調べると，明 らかに癌部選択的にリピオドールの残存が認められる (Fig. 5).

（3）制癌剤の組織内濃度

Lipiodolization 施行後10２4日目に肝切除を行っ

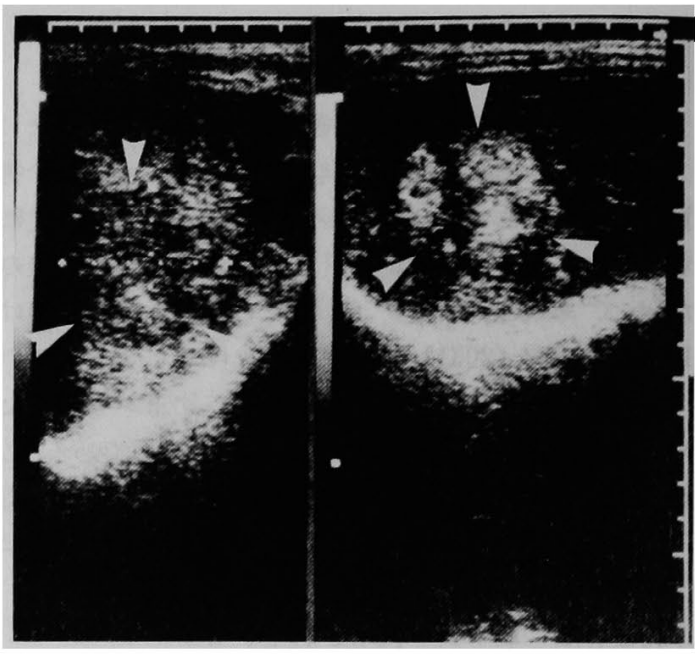

Fig. 3 Ultrasound examination. Before Lipiodolization, the mass appears to be hypoechoic (left). Selective accumulation of oily contrast medium after treatment revealed the tumor to be hyperechoic (right).

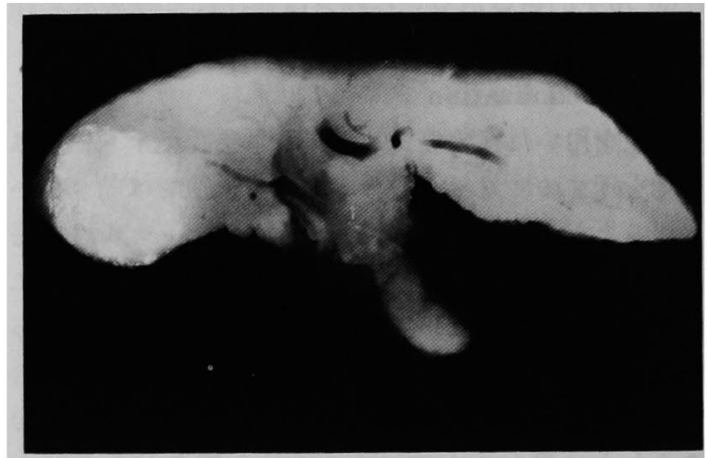

Fig. 4 Soft $x$-ray photography demonstrates selective accumulation of oily contrast material in the neoplasm of the liver (autopsy specimen).

た12症例について，制癌成 ADM の組織内濃度を総蛍 光法で測定してみると，10例(83\%)で癌部の ADM 濃 度が非癌部のそれより高い結果を得た（Table 1).

3）治療効果の判定

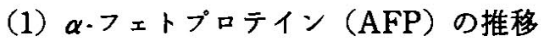

治療前, AFP 值が $1,000 \mathrm{ng} / \mathrm{m} l$ を超える 9 症例中 7 例 $(78 \%$ )で AFP の著減を認め, 中には 4 万 $\mathrm{ng} / \mathrm{ml}$ の ものが 2 回の治療 (ADM 10ng) にて, AFP が正常化 した症例む経験している（Fig. 6).

(2) CT 像

CT 像は, 畽場の縮小奻果をみるに最も, 有用な画像 


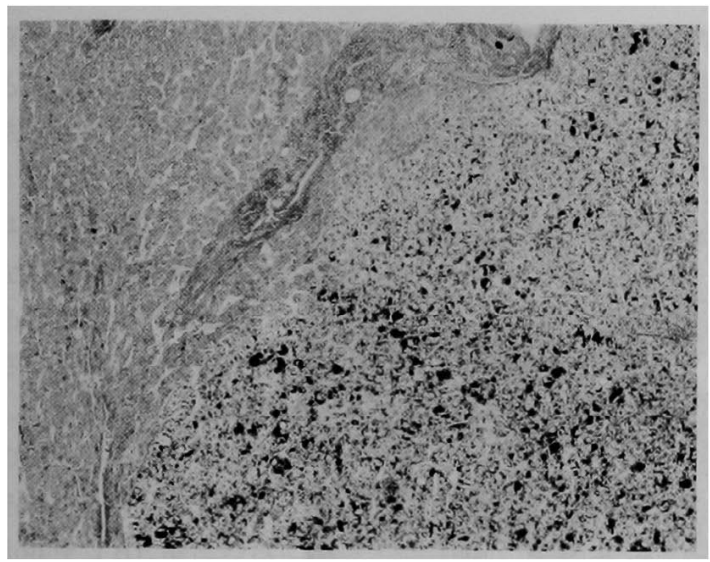

Fig. 5 Osmium tetroxide stain reveals accumulation of Lipiodol (black spots) in the neoplastic lesion of the liver (right). There is no deposit of any oily substance in the liver parenchyma (left).

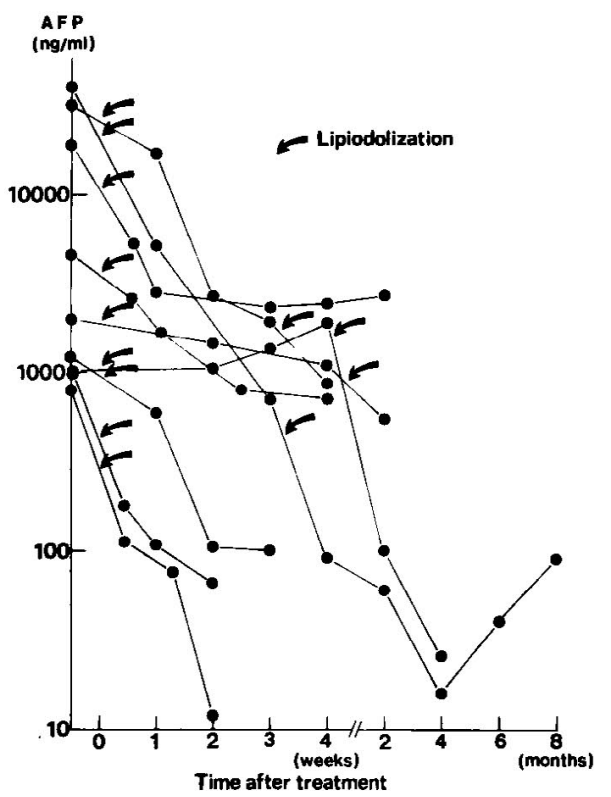

Fig. 6 Serial change of serum alpha-fetoprotein after Lipiodolization.

診断法である（Fig. 7). 我々は，本法施行後 3〜 4 週 目にCT 撮影を行い，腫瘍径を治療前のそれと比較し ている. 現在までに CT で腫瘍径の縮小を誌めたもの は35例中 5 例 (14\%) であった。

(3) 組織学的検索

Lipiodolizationの組織学的検索では, 様々な変化を 示す，尰場が壊死に陥っていることすある．他方，壊
Table 1 ADM concentration in the tissues following Lipiodolization.

\begin{tabular}{r|c|c|c}
\hline Case & Age $/$ Sex & Tumor $(\mu \mathrm{g} / \mathrm{g})$ & $\begin{array}{c}\text { Liver parenchyma } \\
(\mu \mathrm{g} / \mathrm{g})\end{array}$ \\
\hline 1. & $58 / \mathrm{M}$ & 6.3 & 1.3 \\
2. & $53 / \mathrm{M}$ & 11.0 & 2.0 \\
3. & $68 / \mathrm{F}$ & 1.1 & 1.8 \\
4. & $57 / \mathrm{M}$ & 19.0 & 2.0 \\
5. & $57 / \mathrm{M}$ & 6.4 & 1.5 \\
6. & $50 / \mathrm{M}$ & 1.5 & 1.1 \\
7. & $42 / \mathrm{F}$ & $27.0^{*}$ & 0.2 \\
8. & $50 / \mathrm{M}$ & 2.7 & 0.2 \\
9. & $56 / \mathrm{M}$ & 34.0 & 0.2 \\
10. & $54 / \mathrm{M}$ & 1.6 & 0.09 \\
11. & $56 / \mathrm{M}$ & 0.16 & 0.09 \\
12. & $58 / \mathrm{M}$ & 14.0 & 1.4 \\
\hline
\end{tabular}

ADM : Adriamycin

Tumors were hepatocellular carcinoma, except for metastatic liver cancer( $\left.{ }^{*}\right)$ in case 7 and cholangiocarcinoma $(*)$ in case 12.

Intervals between Lipiodolization(ADM $30 \mathrm{mg}$ ) and surgery varied from 10 to 24 days.

Table 2 Transient side effects of Lipiodolization

\begin{tabular}{l|c}
\hline \multicolumn{1}{c|}{ Side effects } & No. of patient(\%) \\
\hline Fever & $32(58)$ \\
Abdominal pain & $12(22)$ \\
Transient liver dysfunction & $11(20)$ \\
Nausea, vomiting & $11(20)$ \\
Pancreatitis & $2(4)$ \\
Headache & $2(4)$ \\
Nil & $12(22)$ \\
\hline
\end{tabular}

死巣の中に生きた癌細胞を認めることもある，また， 主腫瘍は凝固壊死となっているものの, 被膜内に漫潤 した癌細胞には無効であった症例むある (Fig. 8). 睡 痬の血行支配に左右される所見と思われる.

\section{4) 副作用}

本法による副作用は Table 2の如くである. 発熱は 高率に起こるか，3〜5 日で消腿することが殆んどで ある，その他，呕気や腹痛などの副作用があるが，い ずれも軽く，短期間で治まっている，GOT, GPT の上 昇か20\%に認められており，肝炎の活動期では本法の 施行は，差し控えるべきであるら．また，リビオドー ルか，胃十二指腸動脈人流入した昜合に胼炎の発生を 2 例に経験した. 血中フミラーゼの上昇が一過性に認 められたが, 保存的療法で軽快した。 


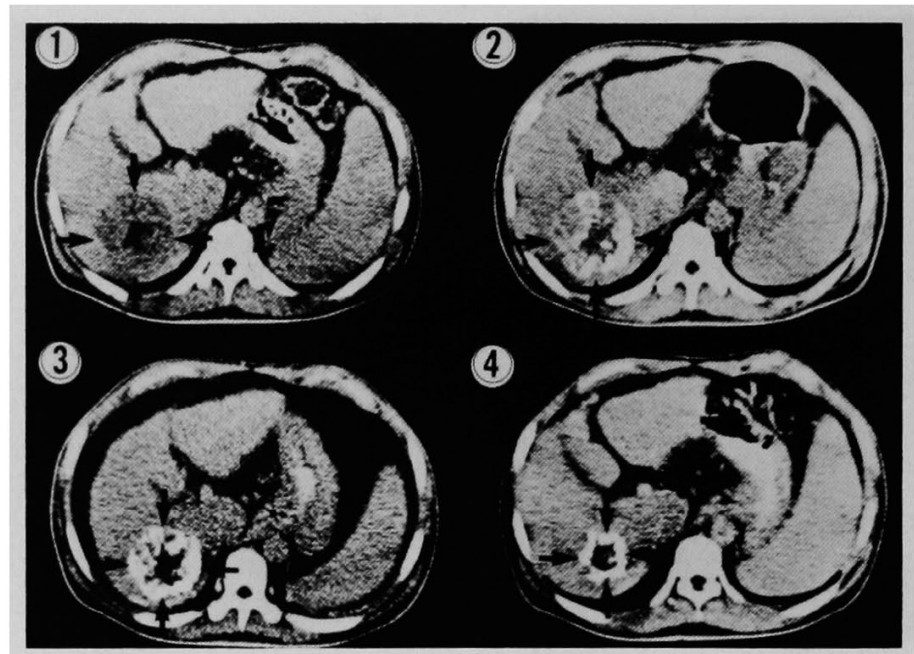

Fig. 7 Computed tomography, (1) A low density area, indicated by arrows, is demonstrated in the right hepatic lobe. (2) CT scan after first Lipiodolization. Selective accumulation of oily material in the mass is evident. (3) The tumor size slightly decrease one week after second treatment. (4) There is an apparent decrease in the size of oily deposit area 8 weeks later.

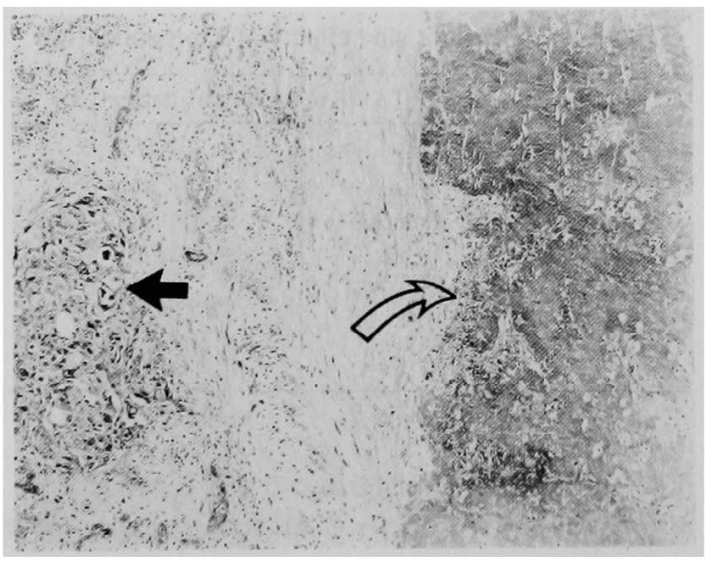

Fig. 8 Microscopic examination reveals main tumor of hepatocellular carcinoma with a complete necrosis (white arrow). However, viable cancer cells are seen within the capsule wall (black arrow) (H \& E stain, $\times 63$ )

$$
\begin{aligned}
& \text { 考察 } \\
& \text { ここで述べた“リピオドール・ウログラフィン”シ }
\end{aligned}
$$
ステムを応用すれば, 殆んどの水溶性制癌剂をりピオ ドールに憅濁化が可能であり，畽瘍に応じた制癌剤の 選択る自由に行い得る。をた，単独制癌剤のみならず， 相乗効果を有する複数薬剂の併用, 寸なわち, 多剂併 用㞠法への道をむ開くものである7!。かも, その調整
法は極めて簡便で，特殊な器具も要らず，清潔操作の 下，短時間に，心要に応じた量の作製が可能であるこ とは, 臨床上, 応用しやすい方法といえよ5。

この Lipiodolizationの適応となるものは，原発性 肝癌のように血行の豊富な腫瘍である。転移性肝癌や 胆管癌なとの乏血性腫瘍には，油性造影剂は停滞しに くい.しかし, 単純レ線上描出されなくても, CT 検査 を行らと腫浧に一致してリピオドールの停滞が認めら れる場合があり，このことは, Lipiodolization と画像 診断法との組合せにより，腫瘍の局在診断や病変の払 がりの判定にも有用ではないかと期待される.

油性造影剤は腫瘍に選択的かつ長期にわたり停滞す るが、この造影剤といっしょに運ばれた制癌剤アドリ フマイシンの組織内濃度は，本療法施行後10 24日目 に肝切除を行った症例の $83 \%$ で癌部の方が, 非癌部に 比べ高かった. Lipiodolizationの抗腫瘍効果は, AFP 值の低下や画像診断による畽場の縮小からる窺えた が，更に組織学的検索でも腫愓の壊死を認めた。しか しながら、このような症例でも被膜内に浸潤した癌紐 胞には無奻のことがあり，本㞠法のみでの根治性には 是問がある。また，娘結節に対する効果については今 後の検討を待たねばならないが, Fig. 2にみる如く、リ ピオドールは娘結節にも良く貯留して招り, 肝内転移 宩への効果も期待できるかる知れない，従来の TAE 
療法は娘結節に対しては無効であり ると，Lipiodolization は，肝切除に併用すべき補助療 法として，より優れたものといえるかる知れない．

我々の経験でも，被膜内に浸潤した癌細胞に対して は効果がなかったが，最近，神代・中島はTAEの効果 を病理学的に唡討し，たとえ TAEの最も良い適応で ある被包型肝癌であっても TAE 療法のみで完全治瘾 させることが困難であることが推察される症例を報告 し,さらに, TAE 後, 癌細胞の変質や他クローン細胞 の增殖が起り，急激な病気の進行をもたらす可能性が あることを示した9?.従って, 胃時点では, Lipiodolization P TAE 療法のみに依存することなく，可能なも のに対しては切除を行うことが，肝癌治療上望ましい といえよう。

経験症例では重篤な合併症は発生しなかった，現在 までに,リンバ管造影, 脊髄造影, 子宮・卵管造影時 に誤って油性造影剤が血管内に混入した症例の報告が あるが，たと光，レ線上，肺野に造影剂が描写される 程度であっても大事に至っていない場合が多 い10 12). しかしながら, Ingersoll 等によれば, 1931年, 60歳の女性の子宮卵管造影後，9時間目に肺，心，腎 に oil emboli を生じ死亡した報告があるという た, Thompson と Anlyan は, 体重30kg の小児が,リ ンパ管造影で $25 \mathrm{ml}$ の油性造影剂の投与を受け，4 日 後に死亡したが，肺野に造影剤の眝留があったことか ら、これが死因に槃がったと考えられる症例の報告が あることを，彼等の著書の中で述べている13)。

従来, 我々が用いてきた量 $(3 \sim 6 \mathrm{~m} l)$ 程度では殆ん と障害がないるのの, 油性造影剂の投与に際しては, その注入量, 注入速度や患者の体重, 全身状態, 基礎 疾患, 更には，治療対象部の動静脈瘦の存在などを充 分考虑した上で，施行することが必要と考える。

\section{女 献}

1) Sheehan R, Hreshchyshyn M, Lin RK, et al: The use of lymphography as a diagnostic method. Radiology 76 : 47-53, 1961
2) Idezuki $Y$, Sugiura $M$, Hatano $S$, et al: Hepatography for detection of small tumor masses in liver: Experiences with oily contrast mediuim. Surgery $60: 566-572,1966$

3）中熊健一朗, 田代征記, 上村邦紀 5 ：進行肝癌に対 する肝動脈結禁術增強効果の試み一とくに結禁肝 動脈内油性造影骫注入について一，日独医報 $24: 675-682,1979$

4）今野俊光, 田代征記, 前田 浩ら：肝癌に対する油 性制癌剂動注療法. 癌と化学療法 $10 ： 351-357$, 1983

5）兼松隆之，井口 食道静脈瘤併存肝癌に対す る治療。日本外科学会雑誌 $84 ： 923-926,1983$

6) Furuta $T$, Kanematsu $T$, Ezaki $T$, et al: Antitumor effects of Lipiodolized doxorubicin on $\mathrm{VX}_{2}$ carcinoma in rabbits. Jpn J Surg (in press)

7) Kanematsu $T$, Inokuchi $K$, Sugimachi $K$, et al : Selective effects of Lipidolized antitumor agents. J Surg Oncol $25: 218-226,1984$

8）岡村 純, 场川真一, 門田守人ら：経カテーテル制 癌剂動注兼塞栓療法. 蹦床科学 $18: 795-805$, 1982

9）神代正道，中島敏郎：病理からみた TAE の効果. 臨床外科 $39: 979-985,1984$

10) Ingersoll FM, Robbins LL : Oil embolism following hysterosalpingography. Am J Obstet Gynecol 53 : 307-311, 1947

11) Fillenlove TM: Venous intravasation during myelography. Radiology 53 : 410-412, 1949

12) Bron KM, Baum S, Abrams HL: Oil embolism in lymphangiography. Radiology $80: 194$ $-202,1963$

13) Thompson LK, III, Anlyan WG: Toxicologic study of an iodinated oil following intralymphatic and intravenous administration into dogs. Surg Obstet Gynecol 121 : 107-111, 1965 


\title{
Selective effects of Lipiodolized antitumor agents on malignant hepatic tumors
}

\author{
Takashi Kanematsu, Kiyoshi InOKUCHI, Toshiya Furuta, Kenji TaKenaKa, \\ Takashi SonodA, Takuhiro EzaKI, Katsuhiko YanagA, Keizo SugIMACHI* \\ Shozo TAMURA and Keiichi MatSUURA**
}

Given through the hepatic artery, Lipiodol remains only in the neoplastic tissue for an extended time and there was no evidence of deposits in liver parenchyma, on the plain x-ray film. We proposed "Lipiodolization" of water-soluble antitumor agents using an intermediate Urografin, a water-soluble contrast medium.

Fifty-two patients with hepatocellular carcinoma and 3 with metastatic liver cancer were treated with this Lipiodol-Urografin system, containing antitumor agent. Marked decrease in serum alpha-fetoprotein levels was evident in $78 \%$, and decrease in tumor size in computed tomography revealed this method to be effective in $14 \%$. Lipiodolization appears to be a new approach to selective cancer chemotherapy.

* Department of Surgery II, Kyushu University, Faculty of Medicine (Fukuoka)

** Department of Radiology, Kyushu University, Faculty of Medicine (Fukuoka) 